\title{
Altitudinal distribution of moths (Lepidoptera) in Mt. Jirisan National Park, South Korea
}

\author{
SEI-WoOng CHOI ${ }^{1}$ and JeOng-SeOP $\mathrm{AN}^{2}$ \\ ${ }^{1}$ Department of Environmental Education and ${ }^{2}$ Department of Biology, Mokpo National University, Jeonnam 534-729, South Korea; \\ e-mails: choisw@mokpo.ac.kr; naneon@nate.com
}

Key words. Lepidoptera, species diversity, moths, altitude, distribution, mid-domain effect, Korea

\begin{abstract}
The relationship between species richness of plants and animals and altitude can be either hump-shaped, a monotonic decrease or increase. In this study the altitudinal distribution of moths on one of the highest mountains in South Korea was investigated. Moths were captured using a UV-light trap from May to October in 2007 and 2008. This revealed that the relationship between the total numbers of moth species and individuals and altitude is hump-shaped. A significant relationship was also recorded between the size of the area at each altitude and moth abundance and richness. However, the evenness index yielded a consistent decrease with increase in altitude because of the dominance of few species at high altitudes. Non-metric multidimensional scaling identified two major axes for the moth assemblage on Mount Jirisan. The correlations between the axes and variables demonstrated that the first axis was strongly correlated with altitude and aspect and the second axis with forest and site location.
\end{abstract}

\section{INTRODUCTION}

Mountains are found on all continents. High altitude ecosystems on mountains differ from all other ecosystems as the environment at high altitudes is uniquely harsh (Mani, 1990). Mountain habitats are spatially and structurally complex when trees or larger shrubs form part of the landscape, producing a mosaic of different habitat types with their own particular vegetation and/or microclimate (Haslett, 1997; Hodkinson, 2005). Utilization of these mosaic patches by different plants and animals may reflect more their specific life history strategies and ability to exploit a particular type of habitat than the total taxonomic diversity present at a particular altitude (Haslett, 1997; Hodkinson, 2005).

Patterns in the altitudinal distribution of species richness have frequently been cited as compelling evidence for hypotheses that propose associations with productivity and ambient energy, as well as past and current climates, since these factors vary with altitude (Rahbek, 2005). Two patterns in the altitudinal distribution of species richness are frequently observed (Rahbek, 2005). The first is a monotonic decrease with altitude. This is expected if resource limitation and thermal constraints govern species diversity (Fiedler \& Beck, 2008). The second is that the pattern of species richness is hump-shaped, the middomain effect (Colwell \& Lees, 2000). This pattern is expected if the geometric constraints on habitat areas change with altitude. Lomolino (2001) indicates that peaks in diversity at intermediate levels along an incline correspond to points where the combined effects of many environmental factors and associated processes promote the co-occurrence of many species. Additionally, several insect groups demonstrate no clear altitudinal trends. For example, grasshoppers on a Mediterranean mountain (Claridge \& Singrao, 1978) and hemipteran insects in
Indonesian tropical rainforests (Casson \& Hodkinson, 1991) exhibit no clear altitudinal trends (Hodkinson, 2005). Therefore, it appears that the changes in species richness with altitude may be determined by more complicated mechanisms than previously believed.

Mount Jirisan National Park (highest peak: 1915 m, area: $440.517 \mathrm{~km}^{2}$ ) includes the highest mountain on the mainland of South Korea. The annual average temperature is $12-13^{\circ} \mathrm{C}$ and annual precipitation is $1,200 \mathrm{~mm}$, mostly falling in summer. The vegetation is divided into three main zones: subalpine $(>1,400 \mathrm{~m})$, cool temperate $(400-1,400 \mathrm{~m})$ and warm temperate $(200-300 \mathrm{~m}$ on southern aspects) (Yim, 1977). The subalpine zone is characterized by coniferous (Abies koreana Wilson, Abies nephrolepisv Maximowicz, Picea jezoensis (Sieb. \& Zucc.) Carriere, Pinus koraiensis Sieb. \& Zucc., Taxas cuspidate Sieb. \& Zucc.) and deciduous (Betula ermani Chamisso, B. costata Trautvetter, Quercus mongolica Fischer, Rhododendron schlippenbachii Maxim. var. schlippenbachii) trees. Below the subalpine zone, the forest consists mainly of deciduous trees, such as Quercus mongolica, Quercus serrata Thunberg, Carpinus laxiflora (Sieb. \& Zucc.) Blume, C. tschonoskii Maxim., Quercus aliena Blume and Quercus variabilis Blume. Trees such as Pinus densiflora Sieb. \& Zucc., Cornus controversa Hemsley, Zelkova serrata (Thunberg) Makino and Fraxinux mandshurica Ruprecht commonly occur on ridges and in valleys at low altitudes. The mountain range runs $34 \mathrm{~km}$ east to west and $26 \mathrm{~km}$ north to south in the southwestern part of Korea and is a barrier to dispersal for many species. Its geographic location and difference in altitude from the majority of the mainland have facilitated many studies on the altitudinal distribution of species richness.

Studies on the patterns in the altitudinal distribution in species richness in Mount Jirisan National Park have 


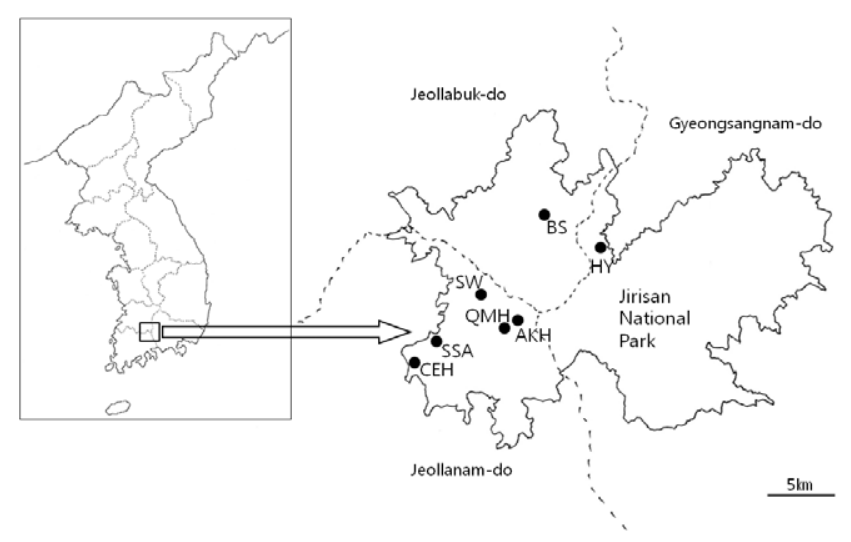

Fig. 1. Location of Mt. Jirisan National Park in South Korea and of the seven sites sampled in the National Park.

revealed it mostly either decreases monotonically or is hump-shaped. Namkung et al. (1972) record a monotonic decrease in spider species richness with increasing altitude over the range of 600 to $1750 \mathrm{~m}$. Lee et al. (2008) compared communities of breeding birds and found that bird species richness and density were higher at low than at high altitudes. However, the species richness of millipedes is highest at middle altitudes $(700 \mathrm{~m})$ (Lim et al., 1992) as is that of soil microarthropods and pseudoscorpions, which peak at 700 and $900 \mathrm{~m}$, respectively (Hong et al., 1996, 1997). Similarly, the distribution with altitude of stone fly species richness (Plecoptera) is also humpshaped with a peak at $750 \mathrm{~m}$ (Ra et al., 1991).

This study sought to determine the altitudinal distribution of moths in Mount Jirisan National Park and the influence of altitude on moth species richness and abundance.

\section{MATERIAL AND METHODS}

\section{Study sites}

Seven sites in the Mount Jirisan National Park in South Korea were sampled in this study (Fig. 1, Table 1). These sites were selected based on accessibility from the lowest CEH $(295 \mathrm{~m})$ to the highest altitude QMH $(1372 \mathrm{~m})$. Of the seven sites, three (CEH, AKH, QMH) were Korea Long-Term Ecological Research sites. Altitudinal area (ha) data for Mount Jirisan National Park was obtained from the Korea Forest Research Institute (Seoul, Korea).

Vegetation at the sites was categorized as either coniferdominant or deciduous-dominant. The vegetation at CEH consisted mainly of pine trees and at AKH mainly of Abies koreana. SSA, BS, HY, SW and QMH were covered with diver- sity of hardwood deciduous trees with little understory vegetation beneath a closed canopy. These seven sites were also designated as either riparian or upland, depending on their proximity to streams. BS, SSA, SW and AKH were designated riparian sites and CEH, HY and QMH upland sites. Two sites (CEH, SSA) were located on southern aspects and the remaining sites on northern aspects.

\section{Moth data and sampling}

The Lepidopteran species targeted included the moth families traditionally falling under the category of Macrolepidoptera (Kristensen \& Skalski, 1999), plus two more readily identifiable families of Microlepidoptera (Limacodidae, Thyrididae). A total of 8,706 individuals belonging to 664 species were identified. Eighteen families were represented in the collections by the following numbers of species: Arctiidae (22), Bombycidae (3), Brahmaeidae (1), Cyclidiidae (1), Drepanidae (24), Endromidae (1), Epiplemidae (2), Geometridae (214), Lasiocampidae (9), Limacodidae (10), Lymantriidae (20), Noctuidae (285), Nolidae (4), Notodontidae (46), Saturniidae (2), Sphingidae (16), Thyrididae (3) and Uraniidae (1). See Appendix 1 for species list.

A light trap consisting of a 22-watt ultraviolet light powered by a $12 \mathrm{~V}$ battery (BioQuip Co., USA) was used to collect insects at each site. Moths were sampled once a month from May to October in 2007 and 2008. To avoid the effect of weather or moonlight on moth catches by each trap, the moths were sampled simultaneously at all seven sites. Moth sampling continued for six hours after dusk. Moths were identified to species and are preserved in a collection at Mokpo National University, South Korea.

\section{Data analysis}

The catches of moths for the two years were pooled. Species richness (total number of species), abundance (total number of individuals), Simpson's diversity index (D) and the Shannon evenness index (E) were calculated for each site (altitude). Simpson's diversity index calculates the probability of any two individuals drawn at random from an infinitely large community belonging to the same species (Magurran, 2003). The Shannon evenness index is $\mathrm{H}^{\prime} /(\ln \mathrm{S})$ where $\mathrm{H}^{\prime}$ is the Shannon diversity index and ( $\ln S)$ is the log-transformed species richness. Altitude, altitudinal area, species richness, and abundance were logtransformed prior to analysis.

Relationships among altitude, altitudinal area, species richness, abundance, diversity and moth evenness were investigated. First, correlation analyses between altitude, altitudinal area and four dependent variables (species richness, abundance, Simpson's D and the Shannon evenness index) were carried out to determine any significant relationships among the variables. Second, a piecewise regression was carried out with a breakpoint at $760 \mathrm{~m}$ (UCLA). The two models were combined into a single model by creating four new variables. Two of the new

TABLE 1. Description of the sites sampled in Mount Jirisan National Park, South Korea. Location of the sites within the park is indicated in Fig.1.

\begin{tabular}{ccccc}
\hline Site & Altitude $(\mathrm{m})$ & Site location & Forest & Aspect \\
\hline CEH & 295 & upland & Conifer & South \\
BS & 518 & riparian & Mixed deciduous & North \\
SSA & 660 & riparian & Mixed deciduous & South \\
HY & 760 & upland & Mixed deciduous & North \\
SW & 923 & riparian & Mixed deciduous & North \\
AKH & 1320 & riparian & Conifer & North \\
QMH & 1372 & upland & Mixed deciduous & North \\
\hline
\end{tabular}


TABLE 2. Summary of the species richness (total number of species), abundance (total number of individuals), Simpson's diversity (D) and Shannon's evenness (E) indices recorded at each of the sites.

\begin{tabular}{|c|c|c|c|c|}
\hline \multicolumn{5}{|c|}{ Site Species richness Abundance Diversity (1-D) Evenness (E) } \\
\hline $\mathrm{CEH}$ & 159 & 660 & 0.97 & 0.846 \\
\hline BS & 314 & 1215 & 0.99 & 0.899 \\
\hline SSA & 268 & 1396 & 0.98 & 0.827 \\
\hline HY & 355 & 1615 & 0.99 & 0.870 \\
\hline SW & 230 & 1330 & 0.95 & 0.768 \\
\hline $\mathrm{AKH}$ & 161 & 1269 & 0.93 & 0.732 \\
\hline QMH & 143 & 1221 & 0.86 & 0.638 \\
\hline
\end{tabular}

variables, alt 1 and alt2, represent the effect of altitude on species richness above and below $760 \mathrm{~m}$, respectively.

alt $1=($ altitude -760$)$, if (altitude $\geq 760)$ alti $1=0$

alt2 $=($ altitude -760$)$, if (altitude $<760)$ alt $2=0$

The other two new variables, int1 and int2, represent the intercepts below and above $760 \mathrm{~m}$, respectively.

int $1=1$, if (altitude $\geq 760$ ) int $1=0$

int $2=1$, if (altitude $<760$ ) int $2=0$

All correlations and piecewise regression analyses were carried out using SPSS (SPSS Inc., 2006).

The relationship between moth assemblage and site location (distance from site to site) was examined using the Mantel test. The Mantel test was undertaken with an initial matrix of seven sites and 402 species (after deleting species unique to particular sites), and using a second matrix of distances (in $\mathrm{km}$ ) between sites. Distance measures for the first and second matrices were Sørensen (Bray-Curtis) and Euclidean distances, respectively. A Monte Carlo randomization test with 999 runs was applied using PC-ORD (ver. 5.17; McCune \& Mefford, 2006).

Non-metric multidimensional scaling (NMDS), an ordination method, was used to compare differences in composition and abundance among samples (McCune \& Grace, 2002). The NMDS procedure was initiated following data transformation, which included the deletion of singletons (species occurring only at one altitude) and log-transformations after adding one to the number caught of each species. A data matrix with seven sampling units and 402 species was produced. The second matrix was created based on four characters, altitude, forest type (conifer vs. mixed deciduous forest), site location (riparian vs. upland), and aspect (northern vs. southern). The significances of the clusters in the NMDS space were calculated using the multiresponse permutation procedure (MRPP), which tests the

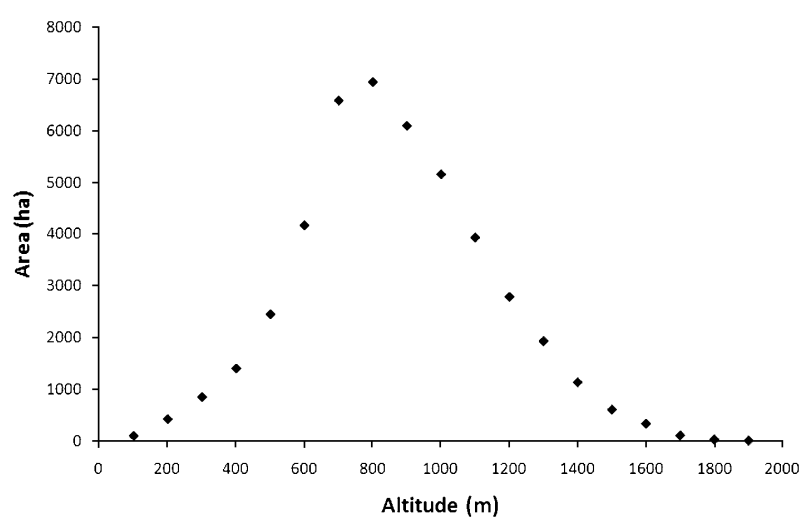

Fig. 2. The relationship between altitudinal area and altitude in Mt. Jirisan National Park, South Korea.

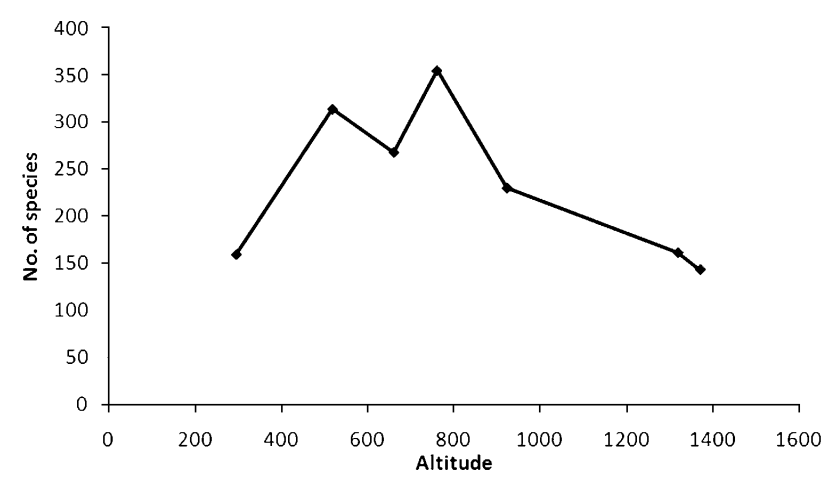

Fig. 3. Hump-shaped relationship between species richness (total number of moth species collected in 2007 and 2008) and altitude in Mt. Jirisan National Park, South Korea.

hypothesis of no difference between two a priori defined groups of entities, in PC-ORD (version 5.17; McCune \& Mefford, 2006).

\section{RESULTS}

The species richness, abundance, diversity and evenness results are detailed in Table 2. The distribution of these variables relative to altitude has a hump-shaped pattern, with the exception of the evenness index (Figs 3-6). There were no significant correlations between species richness, abundance or diversity and altitude. However, the inverse correlation between altitude and evenness is significant (Pearson's $r=-0.766, P=0.045$ ).

The pattern in the distribution of altitudinal area (ha) with increasing altitude is hump-shaped (Fig. 2). Altitudinal area is significantly correlated with species richness (Spearman $\rho=0.793, P=0.033$ ) and abundance (Spearman $\rho=0.847, P=0.016$ ), but not with diversity or evenness. Regression analysis of altitude and altitudinal area revealed a significant relationship between species richness, altitude $(t=5.01, P=0.007)$ and altitudinal area $(t=-3.60, P=0.023)$. In addition, abundance is significantly related to altitudinal area $(t=5.41, P=0.006)$ and evenness to altitude $(t=-4.47, P=0.011)$ (Table 3$)$.

The piecewise regression between log-transformed species and individuals in the catches below and above 760 $\mathrm{m}$ (breakpoint) revealed that species richness is strongly affected by the variables studied above (alt2 $t=-0.34, p$ $<0.05$ ), while species abundance was strongly affected by the variables studied both below (alt1 $t=5.04, p<$ 0.05 ) and above the breakpoint (alt2 $t=-7.53, p<0.05$ ) (Table 4). The relationship between the diversity index and the variables studied is not significant.

TABLE 3. Regression analysis of the abundance, species richness and evenness of moths, altitude and altitudinal area. Simpson's diversity $\mathrm{D}$ is not significantly associated with any of the independent variables. $* P<0.5, * * P<0.05$.

\begin{tabular}{lcccc}
\hline \multirow{2}{*}{ Dependent variable } & \multirow{2}{*}{$\mathrm{R}^{2}$} & \multirow{2}{*}{$F$} & \multicolumn{2}{c}{ Independent variable } \\
\cline { 4 - 5 } & & & Altitude & Altitudinal area \\
\hline Abundance & 0.93 & $27.06^{*}$ & & $5.41^{* *}$ \\
Species richness & 0.87 & $13.41^{*}$ & $-3.6^{*}$ & $5.01^{* *}$ \\
Evenness & 0.83 & $10.03^{*}$ & $-4.47^{*}$ & \\
\hline
\end{tabular}




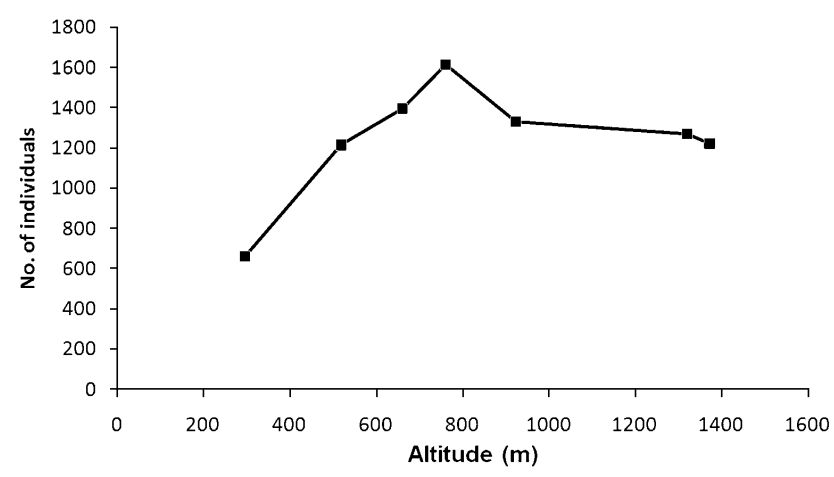

Fig. 4. Hump-shaped relationship between abundance (total number of moths collected in 2007 and 2008) and altitude in Mt. Jirisan National Park, South Korea.

Moth assemblages did not vary according to the distances between sites. The Mantel test revealed that the null hypothesis (no relationship between the site-to-site distance and moth assemblages) was not rejected ( $r=$ $0.16, P=0.25)$. Non-metric multidimensional scaling identified two major axes for moth assemblage on Mount Jirisan (final stress $=0.006$, Fig. 7). The correlations between the two axes and the four variables from the second matrix demonstrated that the first axis is strongly correlated with altitude $(r=0.95)$ and aspect $(r=0.71)$. The second axis, on the other hand, is negatively correlated with forest $(r=-0.51)$ and site location $(r=-0.47)$. The MRPP test did not reject the hypothesis of no relationship between groups for the variables forest $(A=$ $-0.01, P=0.53)$, site location $(A=-0.03, P=0.89)$ and aspect $(A=0.01, P=0.34)$.

\section{DISCUSSION}

Moth assemblages in Mount Jirisan National Park are primarily affected by altitude and altitudinal area. Moth assemblages at different altitudes are not strongly affected by the distance between sites (Mantel test $r=0.16, P=$ $0.25)$. In addition, NMS ordination revealed that the first axis is strongly correlated with altitude $(r=0.95)$ and aspect $(r=0.71)$. This suggests that factors related to altitude and aspect affect the species richness and abundances of moths in Mount Jirisan National Park. As

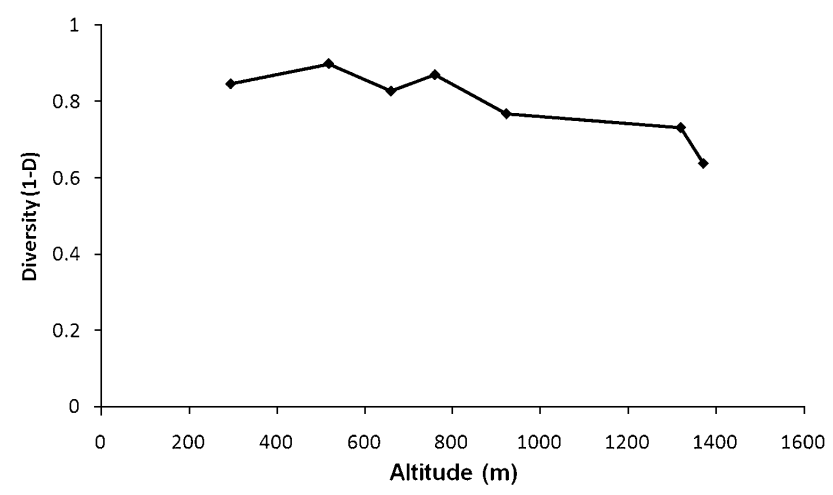

Fig. 5. Relationship between species diversity index of the moths collected in 2007 and 2008 and altitude in Mt. Jirisan National Park, South Korea.

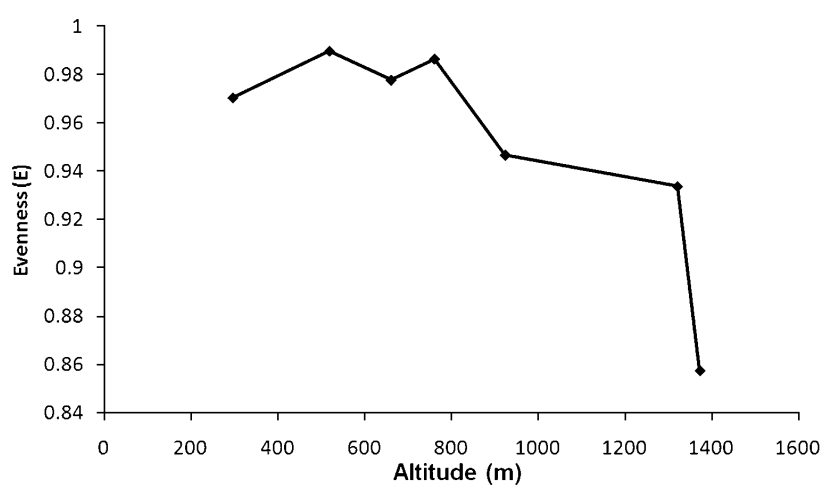

Fig. 6. Monotonic decrease in the relationship between the evenness index of the moths collected in 2007 and 2008 and altitude in Mt. Jirisan National Park, South Korea.

altitude increases, many conditions such as temperature, precipitation, relative humidity, solar radiation, wind and soil conditions change (Körner, 2007; Fiedler \& Beck, 2008). For example, temperature is altitude-specific and decreases by an average of $0.65^{\circ} \mathrm{C}$ for every $100 \mathrm{~m}$ of altitude. Other climatic factors (e.g., precipitation, humidity, wind speed, solar radiation) and geophysical characteristics are also collectively altered by altitude and aspect. Organisms respond to these integrative indicators of environmental change that depend on a multitude of physical and chemical factors along altitudinal gradients (Fiedler \& Beck, 2008; Chen et al., 2009).

The distribution of species richness and abundance of moths relative to altitude in Mount Jirisan National Park is hump-shaped with the peak at $760 \mathrm{~m}$ (Figs 3-4). Species richness strongly decreased above $760 \mathrm{~m}$ and species

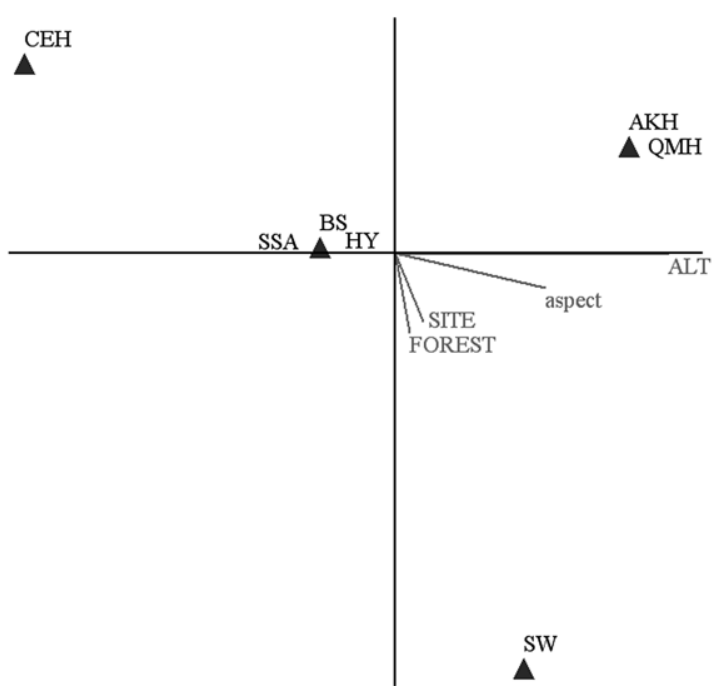

Fig. 7. Non-metric multidimensional scaling graph of 7 sites and 402 moth assemblages in Mount Jirisan National Park (final stress $=0.006,348$ degree rotated). Dark triangles indicate sites and if bearing designations for two or more sites overlapping between sites. Each site is identified in Fig 1. Lines indicate the degree of correlation between moth assemblages and variables. Abbreviations and explanation: site (site location, riparian vs. upland), alt (altitude), forest (forest type, conifer vs. deciduous) and aspect (north vs. south). 
TABLE 4. The results of a piecewise regression analysis of species richness and abundance relative to altitude. Variables, alt1 and alt2, represent the effect of altitude on species richness above and below $760 \mathrm{~m}$ and int 1 and int 2 the intercepts below and above $760 \mathrm{~m} . * P<0.5, * * P<0.05$.

\begin{tabular}{|c|c|c|c|c|c|c|c|}
\hline \multirow{2}{*}{ Dependent variables } & \multirow{2}{*}{$\mathrm{R}_{\mathrm{adj}}^{2}$} & \multirow{2}{*}{ ANOVA $F$-ratio } & \multicolumn{5}{|c|}{ Independent variables } \\
\hline & & & Alt & Alt1 & Alt2 & Int1 & Int2 \\
\hline Log Species & 0.83 & 10.98 & $3.78^{*}$ & & $-3.64 *$ & & \\
\hline \multirow[t]{2}{*}{ Log Individuals } & 0.88 & 15.70 & & $5.04 *$ & & & \\
\hline & 0.98 & 88.69 & $16.00 * *$ & & $-7.53^{*}$ & & $-3.34 *$ \\
\hline
\end{tabular}

abundance increased up to $760 \mathrm{~m}$ and decreased above it. The pattern in the distribution of altitudinal area relative to altitude for Mount Jirisan is also hump-shaped. Regression analyses revealed that altitudinal area is closely related to abundance and species richness, suggesting a close species-area relationship (MacArthur \& Wilson, 1967).

The hump-shaped pattern in the altitudinal distribution of moths is similar to that recorded for other taxa on Mount Jirisan, including millipedes (Lim et al., 1992), microarthropods (Hong et al., 1996), soil pseudoscorpions (Hong et al., 1997) and stoneflies (Ra et al., 1991), although their peaks vary from 700 to $900 \mathrm{~m}$. Fiedler \& Beck (2008) record peaks of from 1000 to $2000 \mathrm{~m}$ for many groups and commented on the range in the values. The difference in the peak values for Korean and other mountains is likely to be a result of differences in the heights of the mountains and their latitudinal position (e.g. tropic, temperate, arctic). Compared to several high mountains in tropical areas, which far exceed $2000 \mathrm{~m}$ a.s.l. (e.g., Papua New Guinea, Hebert, 1980; Andean mountains, Brehm \& Fiedler, 2003; Mt. Kilimanjaro, Axmacher et al., 2004), Mount Jirisan National Park is relatively low, with a height of less than $2000 \mathrm{~m}$ and is located in a temperate zone (latitude $35^{\circ} \mathrm{N}$ ).

Unlike the hump-shaped patterns for the relationships between species richness and abundance relative to altitude recorded in Mount Jirisan National Park, the relationship for evenness consistently decreased with altitude (Fig. 6). Shannon evenness is a measure of heterogeneity that considers the degree of evenness in species abundances in terms of the ratio of observed diversity to maximum diversity (Magurran, 2003). The consistent decrease in evenness recorded in the present study suggests that the observed diversity decreased relative to the maximum diversity. Insect communities at high altitudes are characterized by few species and a greater abundance of individuals (Mani, 1968; Hebert, 1980; Brehm \& Fiedler, 2003). Due to the generally extreme conditions at high altitudes, a high degree of inter-specific integration with concomitant community independence and isolation is one of the peculiar characteristics of high altitude insect communities (Mani, 1968). For example, Brehm \& Fiedler (2003) suggest that the relatively high diversity of larentiine moths (Geometridae) in the Andean mountains may result from low predation pressure at high altitudes. Six species of which more than 170 individuals were caught (about $20 \%$ of total catch of 8,706 individuals) included 970 Hydriollodes morosa (Butler, 1879) (Noctuidae), 589 Lemyra boghaika Tsistjakov \& Kishida,
1994 (Arctiidae), 336 Odontopera arida (Butler, 1878), 320 Alcis angulifera (Butler, 1878), 190 Idaea biselata (Hufnagel, 1767) (Geometridae) and 173 Drymonia dodonides (Staudinger, 1887) (Notodontidae). Among these species, the three most abundant were found primarily at high altitudes (SW, AKH, QMH).

Comparative studies of altitudinal gradients are needed to identify the consistent patterns in scale effects, which can then be used to study the effects of contemporary climate, history and stochastic factors (Rahbek, 2005). Although the pattern in the altitudinal distribution of moths on Mount Jirisan is hump-shaped those for other taxa (e.g. spiders, breeding birds) present on the same mountain are not. While the underlying mechanisms determining the different altitudinal patterns were not examined in the present study; that there are different taxa dependent altitudinal patterns (monotonic decrease vs. hump-shaped) in species richness at the same locality, Mount Jirisan National Park, is intriguing.

ACKNOWLEDGMENTS. We would like to thank to J.-H. Chun, Korea Forest Research Institute, Korea for providing the altitudinal area data and to C.-G. Lee, S.-G. Kim, K.-I. Kim for their help with field trips and to M. Park for identifying moths. We also thank M. Konvička for helpful comments and suggestions. The study was supported by grants from the Ministry of Environment (Korea Long Term Ecological Research Project) and the Korea Research Foundation (KRF 2009-0083863).

\section{REFERENCES}

Axmacher J.C., Holtmann G., Scheuermann L., Brehm G., Müller-Hohenstein K. \& Fiedler K. 2004: Diversity of geometrid moths (Lepidoptera: Geometridae) along an Afrotropical elevational rainforest transect. Divers. Distrib. 10: 293-302.

BrehM G. \& FiedLer K. 2003: Faunal composition of geometrid moths changes with altitude in an Andean montane rain forest. J. Biogeogr. 30: 431-440.

CAsson D.S. \& Hodkinson I.D. 1991: The Hemiptera (Insecta) communities of tropical rain forest in Sulawesi. Zool. J. Linn. Soc. 102: 253-275.

Chen I.-C., Shiu H.-J., Benedick S., Holloway J.D., Chey V.K., Barlow H.S., Hill J.K. \& Thomas C.D. 2009: Elevation increases in moth assemblages over 42 years on a tropical mountain. Proc. Natl. Acad. Sci. USA 106: 1479-1483.

Claridge M.F. \& Singrao J.S. 1978: Diversity and altitudinal distribution of grasshoppers (Acridoidea) on a Mediterranean mountain. J. Biogeogr. 5: 239-250.

Colwell R.K. \& LeEs D.C. 2000: The mid-domain effect: geometric constraints on the geography of species richness. Trends. Ecol. Evol. 15: 70-76.

FIEDLER K. \& BECK E. 2008: Investigating gradients in ecosystem analysis. In Beck E., Bendix J., Kottke I., Makeschin 
F. \& Mosamdl R. (eds): Gradients in a Tropical Mountain Ecosystem of Ecuador. Springer, Berlin, pp. 49-54.

Haslett J.R. 1997: Insect communities and the spatial complexity of mountain habitats. Global Ecol. Biogeogr. Lett. 6: 49-56.

Hebert P.D.N. 1980: Moth communities in montane Papua New Guinea. J. Anim. Ecol. 49: 593-602.

HodKINSON I.D. 2005: Terrestrial insects along elevation gradients: species and community responses to altitude. Biol. Rev. 80: 489-513.

Hong Y., Kiм T.-H. \& OH Y.-C. 1996: Seasonal variance and vertical distribution of soil microarthropods at the Piagol, Mt. Chiri. Kor. J. Ecol. 19: 393-402.

HoNG Y., KIм T.-H. \& Kıм C.-H. 1997: Altitudinal distribution and monthly fluctuation of soil Pseudoscorpions (Arachnida: Pseudoscorpionida) at the Piagol, Mt. Chiri. Kor. J. Ecol. 20: 347-354.

KöRNER C. 2007: The use of altitude in ecological research. Trends Ecol. Evol. 22: 569-574.

KRISTENSEN N.P. \& SKALSKi A.W. 1999: Phylogeny and palaeontology. In Kristensen N.P. (ed.): Lepidoptera, Moths and Butterflies. Vol. 1. Evolution, Systematic and Biogeography. Walter de Gruyter, Berlin, pp. 7-25.

Lee D.-H, Kwon H.-J. \& Song H.-K. 2008: Characteristics of breeding bird community in relation to altitude and vegetation in Jirisan National Park. Kor. J. Envir. Ecol. 22: 471-480.

Liм K.-Y., KIм T.-H. \& KwaK J.-S. 1992: Distribution of millipedes in relation to altitude and flora on Mt. Chiri. Kor. J. Ecol. 15: 329-335.

Lomolino M.V. 2001: Elevation gradients of species-density: historical and prospective views. Global Ecol. Biogeogr. 10: $3-13$.
MacArthuR R.H. \& Wilson E.O. 1967: The Theory of Island Biogeography. Princeton Univ. Press, Princeton, xv +203 pp.

Magurran A.E. 2003: Measuring Biological Diversity. Blackwell, Malden, MA, $260 \mathrm{pp}$.

Mañ M.S. 1968: Ecology and Biogeography of High Altitude Insects. Dr. W. Junk, The Hague, xiv + 527 pp.

Mani M.S. 1990: Fundamentals of High Altitude Biology. 2nd ed. Oxfrod \& IBH publishing, New Delhi, 138 pp.

McCune B. \& Grace J.B. 2002: Analysis of Ecological communities. MjM Software Design, Gleneden Beach, OR, 304 pp.

McCune B. \& MefFod M.J. 2006: PC-ORD. Multivariate Analysis of Ecological Data, Version 5.17. MjM Software Design, Gleneden Beach, OR.

NAmkUng J., PAik W.-H. \& Yoon K.-I. 1972: The spider fauna of Mt. Jiri, Cholla-namdo, Korea. Kor. J. Plant Prot. 11: 91-99.

RA C.-H., Cно Y.-G. \& KIм J.-S. 1991: The seasonal and altitudinal distribution of the Stonefly nymphs (Plecoptera) in Paemsagol Valley of Mt. Chiri, Korea. K. J. Lim. 24: 69-76.

RAHBEK C. 2005: The role of spatial scale and the perception of large-scale species-richness patterns. Ecol. Lett. 8: 224-239.

SPSS INc. 2006: SPSS for Windows. Ver. 14.0. SPSS Inc.

UCLA: Academic Technology Services, Statistical Consulting Group. Introduction to SAS. http://www.ats.ucla.edu/stat/sas/ notes2/ (accessed September 30, 2009).

YIM Y.J. 1977: Distribution of forest vegetation and climate in the Korea Peninsula, IV. Zonal distribution of forest vegetation in relation to thermal climate. Jap. J. Ecol. 27: 269-278.

Received November 18, 2009; revised and accepted January 12, 2010

Appendix 1. List of the moth species sampled at Mount Jirisan National Park from 2007 to 2008. See Fig. 1. for the location and abbreviations of the sites.

\begin{tabular}{|c|c|c|c|c|c|c|c|c|}
\hline Family / scientific name & CHE & BS & SSA & $\mathrm{HY}$ & SW & AKH & QMH & TOTAL \\
\hline \multicolumn{9}{|l|}{$\begin{array}{l}\text { LIMACODIDAE } \\
\end{array}$} \\
\hline Austrapoda dentata (Oberthür, 1879) & 4 & & 1 & & & 1 & & 6 \\
\hline Ceratonema christophi (Graeser, 1888) & 1 & 3 & 1 & 11 & 5 & 4 & & 25 \\
\hline Heterogenea asella (Denis \& Schiffermüller, 1775) & & & & & 1 & & & 1 \\
\hline Latoia hilarata (Staudinger, 1887) & & & & & 1 & & & 1 \\
\hline Latoia sinica (Moore, 1877) & 5 & 10 & 16 & 3 & 1 & 3 & 2 & 40 \\
\hline Microleon longipalpis Butler, 1885 & 1 & 2 & & 1 & 1 & & & 5 \\
\hline Narosa fulgens (Leech, 1889) & 2 & & & & & & & 2 \\
\hline Phrixolepia sericea Butler, 1877 & & 3 & & 2 & & & 1 & 6 \\
\hline Rhamnosa angulata Fixsen, 1887 & 5 & 6 & 1 & & 3 & & & 15 \\
\hline Thosea coreana Okano \& Pak, 1964 & & 1 & & 8 & & & & 9 \\
\hline \multicolumn{9}{|l|}{ DREPANIDAE } \\
\hline Agnidra scabiosa fixseni (Bryk, 1948) & 7 & 4 & 1 & 1 & & & 6 & 19 \\
\hline Auzata minuta nigrata Park \& Shin, 1981 & & 2 & 4 & 9 & 4 & & & 19 \\
\hline Auzata superba (Butler, 1878) & & 2 & 1 & 2 & 5 & 1 & 1 & 12 \\
\hline Callidrepana patrana (Moore, [1866]) & 2 & 3 & 1 & 2 & 4 & & & 12 \\
\hline Demopsestis punctigera (Butler, 1885) & & & & & & & 1 & 1 \\
\hline Deroca inconclusa (Walker, 1856) & 2 & & 3 & & & & & 5 \\
\hline Ditrigona conflexaria (Walker, 1861) & & & & & 2 & & & 2 \\
\hline Ditrigona komarovi (Kurentzov, 1935) & & 1 & 7 & 6 & & & & 14 \\
\hline Ditrigona virgo (Butler, 1878) & & & 2 & & 1 & & & 3 \\
\hline Drepana curvatula acuta Butler, 1881 & & & & 1 & 1 & & & 2 \\
\hline Epipsestis nikkoensis (Matsumura, 1921) & & & & & 1 & & & 1 \\
\hline Epipsestis ornata obscurata Tshistjakov, 1987 & & & & & & 1 & & 1 \\
\hline Euparyphasma maxima (Leech, 1889) & 1 & 1 & 4 & & 1 & 2 & 1 & 10 \\
\hline Habrosyne aurorina (Butler, 1881) & 2 & 19 & & 20 & 10 & 22 & & 73 \\
\hline Habrosyne violacea (Fixsen, 1887) & & & & & 1 & & & 1 \\
\hline Nordstromia japonica (Moore, 1877) & 1 & 17 & 39 & 5 & 24 & 7 & 4 & 97 \\
\hline
\end{tabular}


Parapsestis argenteopicta (Oberthür, 1879)

Pseudalbara parvula (Leech, 1890)

Sabra harpagula olivacea (Inoue, 1958)

Tethea ampliata (Butler, 1878)

Tethea consimilis (Warren, 1912)

Tethea octogesima (Butler, 1878)

Thyatira batis (Linnaeus, 1758)

\section{CYCLIDIIDAE}

Cyclidia substigmaria (Hübner, 1831) THYRIDIDAE

Rhodoneura erecta (Leech, 1889)

Rhodoneura vittula Guenée, 1877

Striglina fixseni Alphéraky, 1897 GEOMETRIDAE

Abraxas latifasciata Warren, 1894

Abraxas niphonibia Wehrli, 1935

Abraxas sylvata (Scopoli, 1762)

Acasis viretata (Hübner, 1799)

Aethalura ignobilis (Butler, 1878)

Aethalura nanaria (Staudinger, 1897)

Agaraeus parva (Hedemann, 1881)

Alcis angulifera (Butler, 1878)

Alcis picata (Butler, 1881)

Alsophila japonensis (Warren, 1894)

Amraica superans (Butler, 1878)

Angerona prunaria (Linnaeus, 1758)

Anticypella diffusaria (Leech, 1897)

Antipercnia albinigrata (Warren, 1896)

Aperia syringaria (Linnaeus, 1758)

Arichanna albomacularia Leech, 1891

Arichanna melanaria (Linnaeus, 1758)

Asthena amurensis (Staudinger, 1897)

Asthena corculina Butler, 1878

Asthena nymphaeata (Staudinger, 1897)

Astygisa chlorophnodes (Wehrli, 1936)

Astygisa morosa (Butler, 1881)

Biston panterinaria (Bremer \& Grey, 1853)

Biston regalis (Moore, 1888)

Brabira artemidora (Oberthür, 1884)

Bupalus vestalis Staudinger, 1897

Cabera griseolimbata (Oberthür, 1879)

Cabera purus (Butler, 1878)

Cabera schaefferi (Bremer, 1864)

Calicha nooraria (Bremer, 1864)

Calleuoype whitelyi (Butler, 1878)

Carige cruciplaga (Walker, 1861)

Cepphis advenaria (Hübner, 1790)

Chiasmia defixaria (Walker, 1861)

Chiasmia hebesata (Walker, 1861)

Chlorissa amphitritaria (Oberthür, 1879)

Chlorissa anadema (Prout, 1930)

Chlorissa macrotyro Inoue, 1954

Chlorissa obliterata (Walker, 1863)

Chloroclystis subcinctata Prout, 1915

Chloroclystis v-ata (Haworth, 1809)

Chloromachia infracta (Wileman, 1911)

Cleora insolita (Butler, 1878)

Comibaena amoenaria (Oberthür, 1880)

Comibaena delicatior (Warren, 1897)

\begin{tabular}{|c|c|c|c|c|c|c|c|}
\hline \multirow[t]{4}{*}{43} & 28 & 101 & 87 & 27 & 25 & 9 & 320 \\
\hline & & & & & 1 & 1 & 2 \\
\hline & & & & & 1 & 1 & 2 \\
\hline & 2 & 1 & 5 & 1 & & & 9 \\
\hline \multirow[t]{2}{*}{5} & 7 & 2 & 18 & 1 & 2 & & 35 \\
\hline & & 1 & & & & 11 & 12 \\
\hline \multicolumn{7}{|l|}{3} & 3 \\
\hline & & & 2 & 1 & & & 3 \\
\hline & & 4 & 3 & 8 & 3 & 3 & 21 \\
\hline \multirow{6}{*}{9} & 4 & 1 & & 3 & & 2 & 19 \\
\hline & & & 1 & & & & 1 \\
\hline & 2 & & 22 & & 2 & 8 & 34 \\
\hline & 7 & 4 & 8 & 9 & & & 28 \\
\hline & & 1 & & & & & 1 \\
\hline & & & 2 & & & & 2 \\
\hline \multirow[t]{14}{*}{1} & & & & & & & 1 \\
\hline & & 1 & 1 & 1 & & & 3 \\
\hline & & & 2 & 1 & & & 3 \\
\hline & 3 & 1 & 5 & & & & 9 \\
\hline & 5 & 24 & 6 & 3 & & & 38 \\
\hline & 7 & 1 & 5 & & & & 13 \\
\hline & 4 & & & & & & 4 \\
\hline & & 2 & & & & & 2 \\
\hline & 1 & 9 & 8 & 4 & & 1 & 23 \\
\hline & 1 & & & & & & 1 \\
\hline & & & 1 & & & 1 & 2 \\
\hline & 4 & 1 & 3 & 1 & & & 9 \\
\hline & 6 & & & 1 & & & 7 \\
\hline & & & 1 & & & & 1 \\
\hline \multirow[t]{7}{*}{2} & 1 & & & & & & 3 \\
\hline & & & 1 & & & & 1 \\
\hline & & & 1 & & & & 1 \\
\hline & & & 1 & & 1 & & 2 \\
\hline & 4 & 1 & 2 & & 1 & & 8 \\
\hline & & & 1 & & & & 1 \\
\hline & 1 & 4 & 6 & 9 & 9 & 7 & 36 \\
\hline \multirow[t]{2}{*}{1} & & & & & & & 1 \\
\hline & 3 & 1 & & 1 & & & 5 \\
\hline
\end{tabular}


Nothomiza aureolaria Inoue, 1982

Obeidia tigrata (Guenée, 1857)

Ocoelophora lentiginosaria (Leech, 1891)

Odontopera arida (Butler, 1878)

Orthocabera sericea Butler, 1879

Orthocabera tinagmaria (Guenée, 1857)

Orthonama obstipata (Fabricius, 1794)

Ourapteryx koreana Inoue, 1993

Ourapteryx subpunctaria Leech, 1891

Oxymacaria normata (Alphéraky, 1892)

Pachyodes superans (Butler, 1888)

Parabapta clarissa (Butler, 1878)

Paradarisa consonaria (Hübner, 1799)

Parapercnia giraffata (Guenee, 1857)

Pareclipsis gracilis (Butler, 1879)

Parectropis nigrosparsa (Wileman \& South, 1917)

Parectropis similaria (Hübner, 1767)

Perizoma saxeum (Wileman, 1911)

Photoscotosia atrostrigata (Bremer, 1864)

Phthonandria atrilineata (Butler, 1881)

Phthonandria emaria (Bremer, 1864)

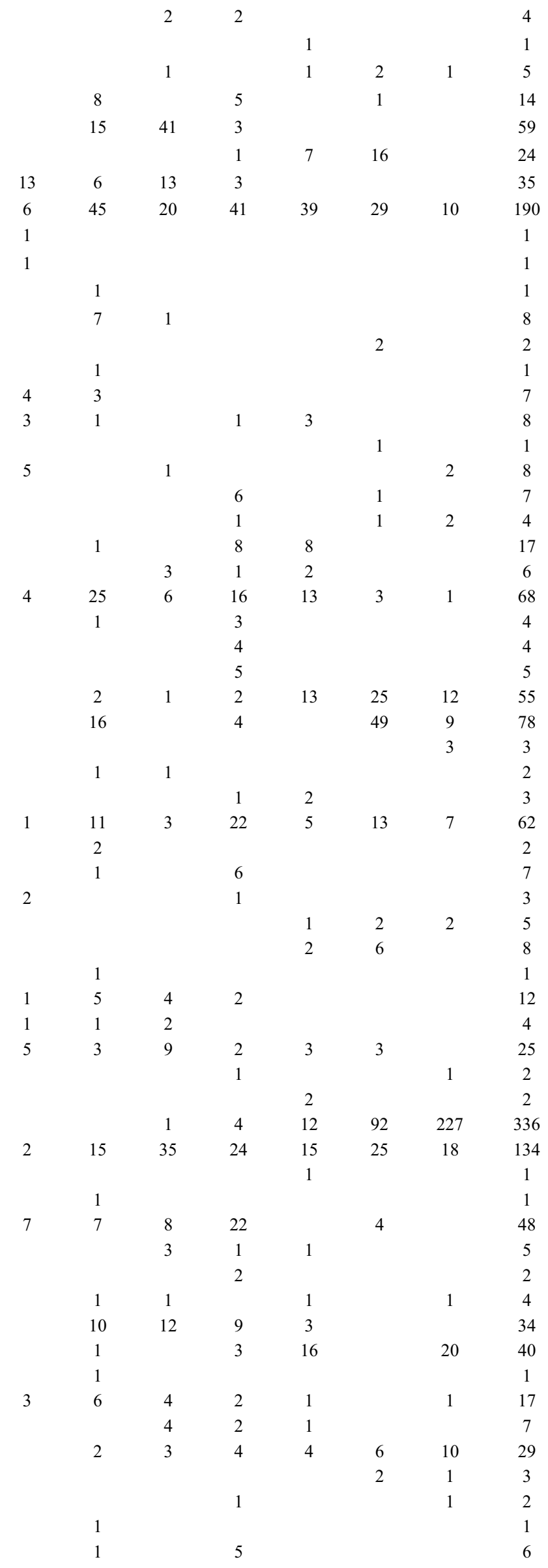


Phthonosema tendinosaria (Bremer, 1864)

Plagodis dolabraria (Linnaeus, 1767)

Plagodis pulveraria (Linnaeus, 1758)

Polymixinia appositaria (Leech, 1891)

Problepsis minuta Inoue, 1958

Problepsis plagiata (Butler, 1881)

Protoboarmia simpliciaria (Leech, 1897 )

Pseudepione magnaria (Wileman, 1911)

Pseuderannis lomozemia (Prout, 1930)

Psyra boarmiata (Graeser, 1892)

Pylargosceles steganioides (Butler, 1878)

Racotis petrosa (Butler, 1879)

Ramobia mediodivisa Inoue, 1953

Rhynchobapta cervinaria (Moore, 1888)

Rikios atoagrisea (Butler, 1878)

Satoblephara parvularia parvularia (Leech, 1891)

Scionomia anomala anomala (Butler, 1881)

Scionomia mendica mendica (Butler, 1879)

Scopula apicipunctata (Christoph, 1881)

Scopula confusa (Butler, 1878)

Scopula ignobilis (Warren, 1901)

Scopula longicerata Inoue, 1955

Scopula modicaria (Leech, 1897)

Scopula nigropunctata (Hufnagel, 1767)

Scopula nupta (Butler, 1878)

Scopula semiignobilis Inoue, 1942

Scopula superior (Butler, 1878)

Selenia sordidaria Leech, 1897

Selenia tetralunaria (Hufnagel, 1767)

Sibatania mactata (Felder \& Rogenhofer, 1875)

Spilopera debilis (Butler, 1878)

Synegia hadassa (Butler, 1878)

Synegia limitatoides Inoue, 1982

Taeniophora unio (Oberthür, 1880)

Telenomeuta punctimarginaria (Leech, 1891)

Thinopteryx crocoptera (Kollar, 1844)

Timandra comptaria Walker, 1863

Timandromorpha enervata Inoue, 1944

Tristrophis veneris (Butler, 1878)

Tyloptera bella bella (Butler, 1878)

Xandrames dholaria Moore, 1868

Xanthorhoe abraxina (Butler, 1879)

Xanthorhoe biriviata (Borkhausen, 1794)

Xanthorhoe hortensiaria (Graeser, 1889)

Xanthorhoe muscicapata (Christoph, 1881)

Xerodes albonotaria (Bremer, 1864)

Xerodes rufescentaria (Motschulsky, [1861])

URANIIDAE

Acropteris iphiata (Guenée, 1857)

\section{EPIPLEMIDAE}

Epiplema moza (Butler, 1878)

Epiplema plagifera (Butler, 1881)

\section{ENDROMIDAE}

Mirina christophi Staudinger, 1887

LASIOCAMPIDAE

Bhima idiota (Graeser, 1888)

Dendrolimus spectabilis (Butler, 1877)

Dendrolimus superans (Butler, 1877)

Euthrix albomaculata (Bremer, 1861)

Euthrix laeta (Walker, 1855)

Gastropacha populifolia angustipennis (Walker, 1885)

Kunugia undans (Walker, 1855) 
Bombyx mandarina (Moore, 1872)

Oberthueria caeca (Oberthür, 1880)

Rondotia menciana Moore, 1885

BRAHMAEIDAE

Brahmaea certhia (Fabricius, 1793)

SATURNIIDAE

Actias artemis (Butler \& Grey, 1853)

Antheraea yamamai (Guérin-Méneville, 1861)

SPHINGIDAE

Acosmeryx naga (Moore, [1858])

Ambulyx japonica Rothschild, 1894

Ampelophaga rubiginosa Bremer \& Grey, [1852]

Callambulyx tatarinovii (Bremer \& Grey, 1852)

Clanis bilineata (Walker, 1886)

Dolbina exacta Staudinger, 1892

Dolbina tancrei Staudinger, 1887

Kentochrysalia consimilis Rothschild \& Jordan, 1887

Kentochrysalia sieversi Alphéraky, 1897

Marumba jankowskii (Oberthür, 1880)

Marumba maackii (Bremer, 1861)

Marumba spectabilis (Butler, 1875)

Marumba sperchius (Ménétriès, 1857)

Meganoton scribae (Austaut, 1911)

Phillosphingia dissimilis (Bremer, 1861)

Psilogramma increta (Walker, [1865])

\section{NOTODONTIDAE}

Allodonta plebeja (Oberthür, 1881)

Clostera albosigma curtuloides Erschoff, 1870

Cnethodonta grisescens Staudinger, 1887

Drymonia dodonides Staudinger, 1887

Dudusa sphigiformis Moore, 1872

Ellida branickii (Oberthür, 1881)

Ellida viridimixta (Bremer, 1861)

Epodonta lineata (Oberthür, 1880)

Euhampsonia cristata (Butler, 1877)

Euhampsonia splendida (Oberthür, 1880)

Fentonia ocypete (Bremer, 1861)

Furcula sangacia (Moore, 1877)

Gangarides dharma Moore, 1866

Gonoclostera timoniorum (Bremer, 1861)

Harpyia umbrosa (Staudinger, 1892)

Hexafrenum leucodera (Staudinger, 1892)

Leucodonta bicoloria ([Denis \& Schiffermüller], 1775)

Lophocosma atriplaga Staudinger, 1892

Lophontosia cuculus Staudinger, 1887

Lophontosia pryeri (Butler, 1879)

Micromelalopha flavomaculata Thistjakov, 1977

Micromelalopha troglodyta (Graeser, 1890)

Neodrymonia coreana Matsumura, 1922

Neodrymonia delia (Leech, 1889)

Neodrymonia marginalis (Matsumura, 1925)

Nerica davidi (Oberthür, 1881)

Notodonta dembowskii (Oberthür, 1879)

Peridea aliena (Staudinger, 1892)

Peridea elzet Kiriakoff, 1963

Peridea gigantea Butler, 1877

Phalera angustipennis Matsumura, 1919

Pheosiopsis cinerea (Butler, 1879)

\begin{tabular}{|c|c|c|c|c|c|c|c|}
\hline & 2 & 2 & 1 & 1 & 3 & 4 & 13 \\
\hline \multirow[t]{9}{*}{2} & 15 & 38 & 14 & 15 & 52 & 37 & 173 \\
\hline & 2 & & 3 & & & & 5 \\
\hline & 3 & 3 & 1 & & & & 7 \\
\hline & & & 4 & 2 & 3 & 2 & 11 \\
\hline & & & 1 & & & 1 & 2 \\
\hline & 1 & & 1 & & & & 2 \\
\hline & 1 & 3 & & & & & 4 \\
\hline & 2 & 1 & 1 & & & 2 & 6 \\
\hline & & 1 & & 1 & & 1 & 3 \\
\hline \multirow[t]{5}{*}{1} & 1 & & 8 & & & & 10 \\
\hline & & & 1 & & & & 1 \\
\hline & 1 & & & & 1 & & 2 \\
\hline & 1 & & & & & & 1 \\
\hline & 1 & & & 3 & 3 & 4 & 11 \\
\hline \multirow[t]{3}{*}{1} & 1 & 2 & 1 & 1 & & 1 & 7 \\
\hline & 1 & 1 & 2 & & & & 4 \\
\hline & & & 1 & & & & 1 \\
\hline \multirow[t]{3}{*}{1} & 10 & & 4 & & & & 15 \\
\hline & 1 & & 2 & & & & 3 \\
\hline & & 1 & & & 1 & 1 & 3 \\
\hline \multirow[t]{4}{*}{9} & 4 & 10 & 2 & 5 & & 3 & 33 \\
\hline & 1 & & & & & & 1 \\
\hline & & & 2 & & & & 2 \\
\hline & & & & 1 & & & 1 \\
\hline \multirow[t]{5}{*}{1} & 2 & & 1 & & & & 4 \\
\hline & 1 & 3 & 2 & 2 & & & 8 \\
\hline & 2 & 6 & 6 & 1 & 3 & 2 & 20 \\
\hline & & & & 1 & & & 1 \\
\hline & & 5 & & 1 & 12 & 10 & 28 \\
\hline
\end{tabular}


Pterostoma sinicum Moore, 1877

Ptilodon hoegei (Graeser, 1888)

Ptilodon ladislai (Oberthür, 1879)

Ptilodon nohirae (Matsumura, 1920)

Semidonta biloba (Oberthür, 1880)

Shaka atrovittatus (Bremer, 1861)

Spatalia dives Oberthür, 1884

Spatalia doerriesi Graeser, 1888

Stauropus fagi persimilis Butler, 1897

Syntypistis cyanea (Leech, 1889)

Syntypistis subgeneris (Strand, 1915)

Togepteryx velutina (Oberthür, 1880)

Torigea straminea (Moore, 1877)

Wilemanus bidentatus ussuriensis (Püngeler, 1912)

LYMANTRIIDAE

Arctornis album (Bremer, 1861)

Arctornis kumatai Inoue, 1956

Arctornis l-nigrum (Müller, 1764)

Calliteara argentata (Butler, 1881)

Calliteara lunulata (Butler, 1877)

Cifuna locuples Walker, 1855

Euproctis piperita Oberthür, 1880

Euproctis pulverea (Leech, 1888)

Euproctis similis (Fuessly, 1775)

Ilema eurydice (Butler, 1885)

Ilema jankowskii (Oberthür, 1884)

Ilema nachiensis (Marumo, 1917)

Ivela auripes (Butler, 1877)

Leucoma salicis (Linnaeus, 1758)

Lymantria mathura Moore, 1865

Lymantria monacha (Linnaeus, 1758)

Numenes albofascia (Leech, 1889)

Numenes disparilis Staudinger, 1887

Parocneria furva (Leech, 1888)

Pida niphonis (Butler, 1881)

\section{ARCTIIDAE}

Aglaeomorpha histrioi (Walker, 1855)

Agrisius fuliginosus Moore, 1872

Agylla collitoides (Butler, 1885)

Chionarctia nivea (Ménétriès, 1859)

Cyana adelina (Staudinger, 1887)

Cyana hamata (Walker, 1854)

Eilema cribrata (Staudinger, 1887)

Eilema deplana (Esper, 1789)

Eilema griseola (Hübner, 1792)

Eilema japonica (Leech, 1888)

Eilema sororculum (Hufnagel, 1766)

Lemyra boghaika Tsistjakov \& Kishida, 1994

Lithosia quadra (Linnaeus, 1785)

Miltochrista aberrans Butler, 1877

Miltochrista miniata (Forester, 1771)

Miltochrista pulchera Butler, 1877

Miltochrista striata (Bremer \& Grey, 1853)

Paraona staudingeri Alphéraky, 1897

Pelosia noctis (Butler, 1881)

Spilarctia seriatopunctata (Motschulsky, 1860)

Spilarctia subcarnea (Walker, 1885)

Spilosoma album (Bremer \& Grey, 1853) NOLIDAE 
Calyptra fletcheri (Berio, 1956)

Catocala dissimilis Bremer, 1861

Catocala doerriesi Staudinger, 1888

Catocala dula Bremer, 1861

Catocala duplicata Butler, 1885

Catocala jonasii Butler, 1877

Catocala nubila Butler, 1881

Cerastis violetta Boursin, 1955

Chasminodes albonitens (Bremer, 1861)

Chasminodes atrata (Butler, 1884)

Chasminodes cilia (Staudinger, 1888)

Chasminodes nigrilinea (Leech, 1889)

Chytonix albonotata (Staudinger, 1892)

Cidariplura gladiata Butler, 1879

Clavipalpula aurariae (Oberthür, 1880)

Colobochyla salicalis ([Denis \& Schiffermüller], 1775)

Colocasia mus (Oberthür, 1884)

Corgatha dictaria (Walker, 1861)

Corgatha nitens (Butler, 1879)

Corsa petrina (Butler, 1879)

Cosmia sanguinea Sugi, 1955

Cosmia trapezina (Linnaeus, 1758)

Cranionycta albonigra (Herz, 1904)

Cranionycta jankowskii (Oberthür, 1880)

Cranionycta oda de Lattin, 1949

Craniophora ligustri ([Denis \& Schiffermüller], 1775)

Craniophora praeclara (Graeser, 1890)

Ctenoplusia albostriata (Bremer \& Grey, 1853)

Cucullia artemisiae (Hufnagel, 1766)

Daseochaeta viridis (Leech, 1889)

Diachrysia leonina (Oberthür, 1884)

Diarsia canescens (Butler, 1878)

Diarsia deparca (Butler, 1879)

Diarsia pacifica Boursin, 1943

Diarsia ruficauda (Warren, 1909)

Dimorphicosmia variegata (Oberthür, 1879)

Dinumma deponens Walker, 1858

Diomea discisigna Sugi, 1963

Diomea jankowskii (Oberthür, 1880)

Dryobotodes angusta Sugi, 1980

Dysmilichia gemella (Leech, 1889)

Earias pudicana Staudinger, 1887

Ectogonia butleri (Leech, 1900)

Edessena hamada (Felder \& Rogenhofer, 1874)

Enispa bimaculata (Staudinger, 1892)

Enispa lutefascialis (Leech, 1889)

Ercheia niveostrigata Warren, 1913

Ercheia umbrosa Butler, 1881

Erebus ephesperis (Hübner, [1823])

Erythroplusia pyropia (Butler, 1879)

Erythroplusia rutilifrons (Walker, 1858)

Eucarta fasciata (Butler, 1878)

Euplexia lucipara (Linnaeus, 1758)

Euromoia subpulchra (Alphéraky, 1897)

Euxoa sibirica (Boisduval, 1834)

Gabala argentata Butler, 1878

Gelastocera exusta Butler, 1877

Gerbathodes paupera (Staudinger, 1892)

Gonepatica opalina (Butler, 1879)

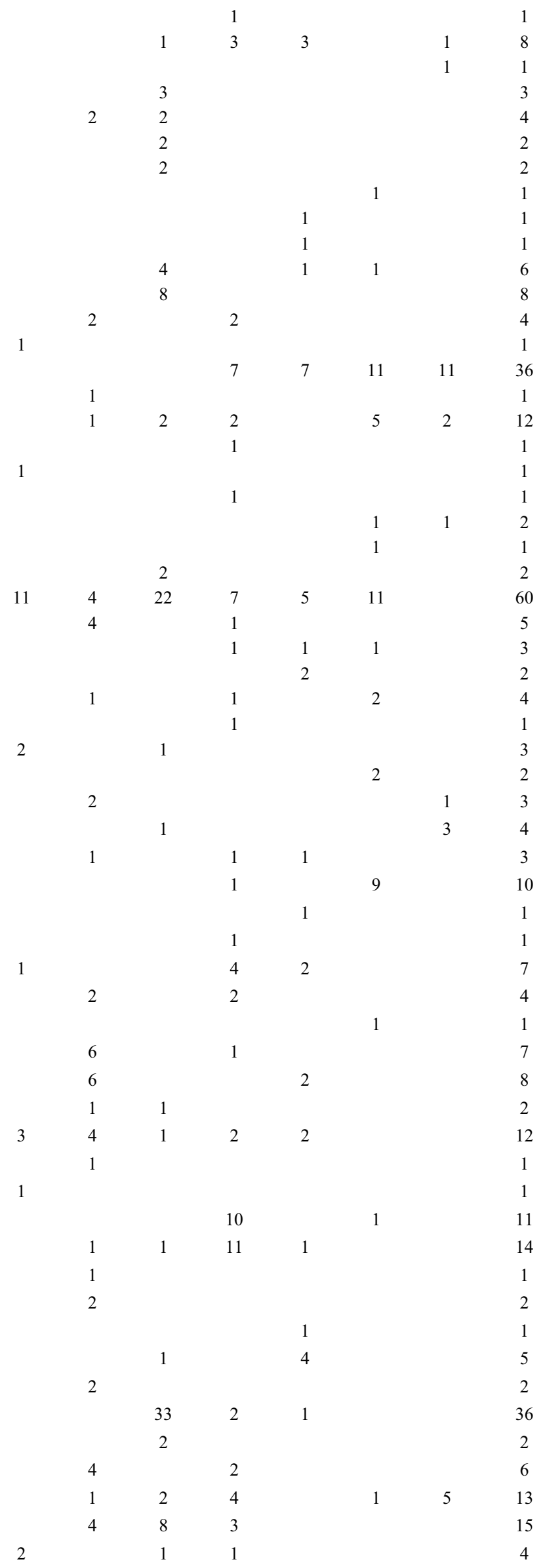


Herminia innocens Butler, 1878

Herminia tarsicrinalis (Knoch, 1782)

Hermonassa arenosa (Butler, 1881)

Hermonassa cecilia Butler, 1878

Hipoepa fractalis (Guenée, 1854)

Hoplodrina euryptera Boursin, 1937

Hydrillodes morosa (Buter, 1879)

Hypena albopunctalis Leech, 1889

Hypena amica (Butler, 1878)

Hypena nigrobasalis (Herz, 1904)

Hypena sagitta (Fabricius, 1775)

Hypena squalida Butler, 1878

Hypena stygiana Butler, 1878

Hypena trigonalis (Guenée, 1854)

Hypena tristalis Lederer, 1853

Hypena zilla Butler, 1879

Hypenomorpha calamina (Butler, 1879)

Hyperstrotia flavipuncta (Leech, 1889)

Hypersypnoides astrigera (Butler, 1885)

Hypocala rostrata (Fabricius, 1794)

Hyposemansis albipuncta (Wileman, 1914)

Iambia japonica Sugi, 1958

Idia quadra (Graeser, [1889])

Iragaodes nobilis (Staudinger, 1887)

Kerala decipiens (Butler, 1878)

Koyaga falsa (Butler, 1885)

Koyaga numisma (Staudinger, 1888)

Lacanobia contrastata (Bryk, 1942)

Lacanobia dentata (Kononenko, 1981)

Leiostola mollis (Butler, 1879)

Leucapamea askoldis (Oberthür, 1880)

Lithophane nagaii Sugi, 1958

Lophomilia flaviplaga (Warren, 1912)

Lophoruza pulcherrima (Butler, 1879)

Lygephila recta (Bremer, 1864)

Macdunnoughia purissima (Butler, 1878)

Maliattha bella (Staudinger, 1888)

Maliattha chalcogramma (Byrk, 1948)

Maliattha rosacea (Butler, 1889)

Meganephria extensa (Butler, 1879)

Melanchra persicariae (Linnaeus, 1761)

Micreremites pyraloides Sugi, 1982

Microxyla confusa (Wileman, 1911)

Mocis ancilla (Warren, 1913)

Mocis annetta (Butler, 1878)

Moma alpium (Osbeck, 1778)

Mosopia sordidum (Butler, 1879)

Mythimna divergens Butler, 1878

Mythimna grandis Butler, 1878

Mythimna loreyi (Duponchel, 1827)

Mythimna monticola Sugi, 1958

Mythimna placida (Butler, 1878)

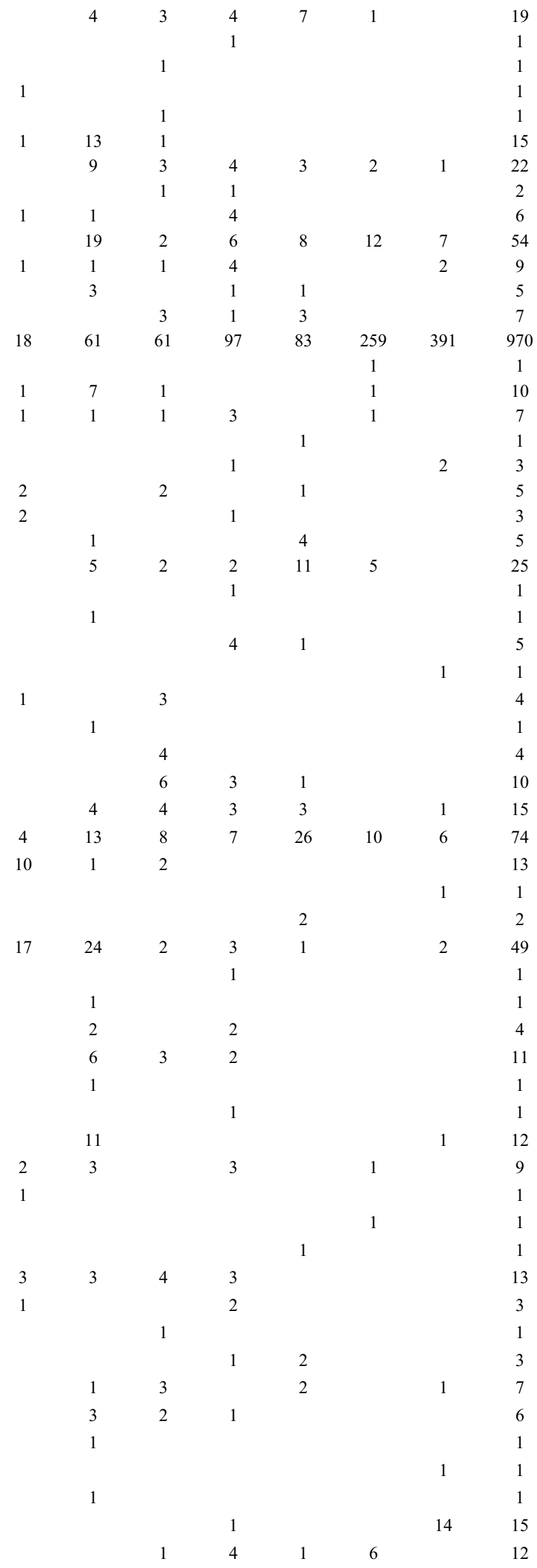


Paracolax contigua (Leech, 1900)

Paracolax fascialis (Leech, 1889)

Paracolax fentoni (Butler, 1879)

Paracolax pryeri (Butler, 1879)

Paracolax trilinealis (Bremer, 1864)

Paracolax tristalis (Fabricius, 1794)

Paragabara flavomacula (Oberthür, 1880)

Paragabara ochreipennis Sugi, 1962

Paragona inchoata (Wileman, 1911)

Peridroma saucia (Hübner, [1808])

Perinaenia accipiter (Felder \& Rogenhofer, 1874)

Prometopus flavicollis (Leech, 1889)

Prospalta cyclica (Hampson, 1908)

Protodeltote maculana Ahn, 1998

Protodeltote pygarga (Hufnagel, 1766)

Protomiselia bilinea (Hampson, 1905)$$
1
$$

Pseudoips faganus (Fabricius, 1781)

Pygopteryx suava Staudinger, 1887

Pyrrhidivalva sordida (Butler, 1881)

Rhizedra lutosa (Hübner, [1803])

Rivula sericealis (Scopoli, 1763)

Sarbanissa subflava (Moore, 1877)

Sarbanissa venusta (Leech, [1889])

Scedopla diffusa Sugi, 1959

Schrankia separatalis (Herz, 1904)

Scoliopteryx libatrix (Linnaeus, 1758)

Sesamia turpis (Butler, 1879)

Siglophora ferreilutea Hampson, 1895

Siglophora sanguinolenta (Moore, 1888)

$\begin{array}{ccccc}1 & 1 & & & 2 \\ & 14 & 26 & 2 & 42 \\ 2 & 2 & & 2 & 1 \\ & & 1 & & 7 \\ & & 1 & & 1 \\ 2 & & & & 2 \\ 1 & 2 & & & 3 \\ 1 & 1 & 2 & & 4\end{array}$


